\title{
PRAKTIK DISTRIBUSI ZAKAT KONSUMTIF TRADISONAL DI KARANG PENANG SAMPANG
}

\author{
HARISAH \\ Institut Agama Islam Negeri (IAIN) Madura \\ Email: harisah@iainmadura.ac.id \\ Zainulloh \\ STAI Miftahul Ulum Pamekasan \\ Email: zainolain15@gmail.com
}

\begin{abstract}
:
The position of zakat in economics of islam is very important, not only as part of the pillars of islam, but also as an indicator of economic development in Islam. Through zakat distribution will be conveyed to those who are entitled. However, the development of increasingly modern economics requires economic actors to be more sensitive to look at situation as well and for the distribution of zakat which should not always be consumptive as like district of karang Penang Sampang but more than it, the productive distribution of zakat will be able become one of the methods of economic development by making zakat funds as capital in growing up the community's economy. Based on discussion are two problems which become the principle for this research, they are how a strategy the distribution of zakat in district of karang penang and how the positive impact for the choosen strategy. The researcher used a qualitative approach method with a type of field research in this research. The data obtained from interviews, observation to location, and making documentation. The result of research are, for the first is the distribution of zakat with traditional comsumptive strategy and The second is The positive impact for the distribution of zakat as just fullfil needs can not be developed to become productive funds and develop the community's economic).
\end{abstract}

Keywords: Practice, Zakat, Distribution, Karang Penang

Abstrak
Zakat menduduki posisi yang sangat penting dalam perekonmian Islam, tidak saja
menjadi bagian rukun Islam, tetapi juga menjadi indikator untuk pengembangan
perekonomian dalam Islam. Melalui distribusi zakat akan tersampaikan kepada mereka
yang berhak. Namun, dari pengembangan perekonomian semakin modern menuntut
para pelaku ekonomi untuk lebih peka membaca kehidupan begitu pula dengan
Ulumuna: Jurnal Studi Keislaman
Vol.5 No.2 Desember 2019:
P-ISSN 2442-8566
E-ISSN 2685-9181


distribusi zakat yang seharusnya tidak selalu bersifat konsumtif seperti di Karang Penang Sampang akan tetapi lebih dari yang demikian, dengan distribusi zakat yang bersifat produktif sehingga dana zakat akan bisa menjadi salah satu metode pengembangan ekonomi dengan menjadikan dana zakat sebagai modal dalam menumbuhkan perekonomian masyarakat. Berdasarkan hal tersebut ada dua permasalahan yang menjadi kajian pokok dalam penelitian ini bagaimana strategi distribusi zakat di Karang Penang serta bagaimana nilai positif dari strategi distribusi zakat tersebut. Dalam penelitian ini peneliti menggunakan metode pendekatan kualitatif dengan jenis penelitian lapangan (field research), data ini diperoleh dari wawancara, observasi ke lokasi penelitian dan dokumentasi. Hasil penelitian menunjukkan bahwa: pertama distribusi zakat dengan strategi konsumtif tradisional kedua nilai positif dari distribusi zakat hanya untuk memenuhi kebutuhan tidak bisa dikembangkan untuk menjadi dana produktif dan pengembangan perekonomian masyarakat.

Kata Kunci: Praktik, Zakat, Distribusi, Karang Penang

\section{Pendahuluan}

Penumpukan harta pada sebagian orang cenderung menimbulkan masalah sosial.Dengan demikian, Islam sangat melarang penumpukan suatu harta sehingga harta menurut Islam harus difungsikan dan didistribusikan.Distribusi harta difungsikan sebagai satu metode dan instrumen yang bisa memberdayakan masyarakat miskin,dan memberikan kemudahan masyarakat miskin untuk mendapatkan akses modal untuk berusaha. ${ }^{1}$ Salah instrumen tersebut adalah zakat Oleh karena itu setiap muslim yang telah wajib mengeluarkan zakat hendaknya patuh untuk menunaikan perintah berzakat dan selalu berusaha untuk mewujudkan kedermawanan dengan berinfak di jalan Allah sehingga dibutuhkan suatu mnajemen yang bisa mendistribuskan harta. ${ }^{2}$ Zakat merupakan salah satu instrumen Islami yang digunakan untuk distribusi pendapatan dan kekayaan.Adanya zakat firah, zakat maal dan zakat profesi diharapkan dapat menekan tingkat ketimpangan kekayan di Indonesia, selain itu juga zakat dapat diandalakan sebagai salah satu mekanisme dalam mengatasi masalah kemiskinan yang terjadi di Indonesia, melalui program zakat produktif.

Nilai positif dari penerapan konsep Islam salah satunya dari zakat tersebut yang didistribusikan.Distribusi yang tujuannya untuk pengembangan perekonomian haruslah harta zakat yang didistribusikan secara produktif akan

${ }^{1}$ Yoghi Citra Pratama "Peran Zakat Dalam Penanggulangan Kemiskinan (Studi Kasus : Program Zakat Produktif Pada Badan Amil Zakat Nasional)" The Journal Of Taubidinomics Vol. 1 No. 1 (2015), hlm 94.

${ }^{2}$ Widi Nopiardo "Mekanisme Pengelolaan Zakat Produktif Pada Badan Amil Zakat Nasional Tanah Datar” JEBI (Jurnal Ekonomi dan Bisnis Islam)-Vol. 1, No. 2 (Juli-Desember 2016), hlm 185. 
tetapi banyak desa yang memiliki potensi pengembangan zakat namun tidak terealisasi karena disribusi zakat dilakukan dengan cara konsumtif. Pada kenyataannya pengembangan ekonomi mencerminkan bahwa kehidupan itu haruslah selaras dan saling melengkapi, dengan disribusi zakat ini memberikan nilai secara sistem kehidupan ekonomi bukan menciptakan mereka yang kaya untuk semakin kaya, dan begitu sebaliknya.

Penyaluran dana zakat dilakukan terhadap beragam kebutuhan masyarakat, apakah itu semata untuk individu (konsumtif) dan juga untuk zakat produktif yang nantinya bisa dikembangkan oleh mustabiqhingga akhirnya ia juga mampu menjadi muzakki. ${ }^{3}$ Dari sisi tingkat kebutuhan mustahiq, ada perhitungan dalam menetapkan besarnya bagian harta zakat yang diperoleh dari perhitungan ini pula bisa menentukan dana zakat yang akan didistribusikan. Zakat merupakan stimulus guna membangkitkan potensi karya dan produktivitas ekonomi dalam kehidupan masyarkat yang harus diyakini bahwa para mustahik pun memiliki potensi konstribusi terhadap kehidupan masyarakat yang selama ini dihargai sangat rendah oleh masyarakat. ${ }^{4}$ Sehingga perlu muzakki memiliki pengembangan pemikiran karena salah satu peraturan penting dalam ekonomi Islam ialah membangun suatu sistem distribusi yang adil daripada distribusi yang sama terhadap kekayaan dan menjadikan pengembangan perekonomian.

Dalam beberapa penelitian menjelaskan nilai positif dari zakat misalanyapengentasan kemiskinan,kesenjangan sosial, pengangguran, dan kesenjangan ekonomi (pendapatan) merupakan beberapa contoh permasalahan yang dapat dipecahkan dengan zakat.Hal ini dapat dilakukan melalui optimalisasi pengumpulan dan distribusi zakat secara efektif kepada pihak yang berhak menerima. ${ }^{5}$ Irfan Syauqi Beik dalam penelitiannya menjelaskan bahwa distribusi zakat dengan cara produktif akan memberikan nilai positif untuk mengembangakan perekonomian masyarakat menunjukkan bahwa zakat mampu mengurangi jumlah keluarga miskin dari 84 persen menjadi 74 persen. Kemudian dari aspek kedalaman kemiskinan, zakat juga terbukti mampu mengurangi kesenjangan kemiskinan dan kesenjangan pendapatan, yang diindikasikan oleh penurunan nilai P1 dari Rp 540.657,01 menjadi Rp 410.337,06 dan nilai I dari 0,43 menjadi 0,33. Sedangkan ditinjau dari tingkat

${ }^{3}$ Hebby Rahmatul Utamy, "Keadilan Ekonomi Dalam Pendistribusian Zakat Oleh Badan Amil Zakat Nasional (Baznas)Kabupaten Tanah Datar" Jurnal Tamwil, Vol. I, No. 2 (Juli-Desember 2015), hlm 3.

${ }^{4}$ Dini Fakhriah,"Efektivitas Penyaluran Dana Zakat Di BAZNAS Kota Bekasi Dalam Peningkatan Pendidikan Melalui Program Bekasi Cerdas" Skripsi, Konsentrasi Manajemen Zakat Dan Wakaf Program Studi Mumalah Fakultas Syariah UIN Syarif Hidayatulh Jakarta (2016), 1.

${ }^{5}$ Achmad Syaiful Hidayat "Model Tatakelola Badan Dan Lembaga Amil Zakat Sebagai Upaya Untuk Meningkatkan Pemberdayaan Ekonomi Masyarakat (Studi Pada Badan/Lembaga Amil Zakat Di Kota Malang)" Anwar Jurnal Humanity, ISSN: 0216-8995 Vol. 7, No. 2, (Juli 2012), 1. 
keparahan kemiskinan, zakat juga mampu mengurangi tingkat keparahan kemiskinan yang ditandai dengan penurunan nilai Indeks Sen (P2) dari 0,46 menjadi 0,33 dan nilai indeks FGT dari 0,19 menjadi $0,11 .{ }^{6}$ Dari beberapa penelitian ini bisa dikatakan bahwa zakat merupakan salah satu instrument dalam Islam untuk mendistribusikan kekayaan kepada umat, karena zakat ini juga bisa dikatakan sebagai alat diatribusi non pasar atau alat diatribusi kekayaan tanpa harus Ada pertujaran.

Bagitu pula dengan hasil Hebby Rahmatul Utamy yang menyatakan Strategi BAZNAS Kabupaten Tanah Datar dalam menetapkan kuota calon mustahiq di setiap kecamatan dilakukan berdasarkan berapa besarnya dana zakat yang masuk dari setiap kecamatan tersebut, ini berpengaruh terhadap pemerataan distribusi di seluruh daerah. Karena untuk kecamatan dengan setoran dana zakat yang masih sedikit berimplikasi kepada sedikitnya kuota mustabiq di daerah tersebut, sehingga Pendistribusian zakat oleh BAZNAS seharusn yamemberi andil dalam mewujudkan kesejahteraan dan keadilan ekonomi, karena BAZNAS dan murakki diharapkan mampu menggunakan dengan baik sumber-sumber ekonomi yang ada, belum terlaksana secara maksimal $^{7}$ hal ini menunjukkan bahwa distribusi zakat seharusnya tidak hanya diruang lingkup daerah yang mengeluarkan harta zakat. Akan tetapi, zakat merupkan bentuk staregi yang bisa membagunperekonomian nasional. Hal ini karena dengan diatribusi zakat yang baik, maka akan menimbulkan pemerataan dalam perekonomian. Hal positif lain adanya peluang bagi fakir Dan miskin juga menjadi pengelola usaha dengan harta zakat yang didapatkan dari muzakki.

Penelitian lain juga diungkapkan oleh Mukhlisin dalam penelitiannya dikatan bahwa faktor penghambat dalam pendistribusian zakat untuk pemberdayaan ekonomi masyarakat antara lain kurangnya pemahaman masyarakat untuk sadar akan arti berzakat, kurangnya pemahaman masyarkat akan adanya lembaga zakat serta kurangnya kepercayaan masyarakat terhadap lembaga pengelola zakat sehingga masih banyak masyarkat dalam distribusi zaktanya berrsifat tradisional. ${ }^{8}$ Sehingga distribusi zakat sangat membutuhkan strategi untuk memberikan hasil maksimal dan nilai positif pada pendapatan masyarakat sehingga akan berpengaruh pula pada konsumsi masyarkat, hal ini sesuai dengan hasil penelitian Elok Nurlita dan Marlina Ekawaty dijelaskan zakat yang diterima dan jumlah anggota rumah tangga berpengaruh terhadap

\footnotetext{
${ }^{6}$ Irfan Syauqi Beik “Analisis Peran Zakat dalam Mengurangi Kemiskinan : Studi Kasus Dompet Dhuafa Republika Zakat \& EmpoweringJurnal Pemikiran dan Gagasan - Vol II (Agustus 2009), 12.

${ }^{7}$ Hebby Rahmatul Utamy, "Keadilan Ekonomi Dalam Pendistribusian Zakat Oleh Badan Amil Zakat Nasional (Baznas) Kabupaten Tanah Datar" Jurnal Tamwil, Vol. I, No. 2, (Juli-Desember 2015), 16.

${ }^{8}$ Mukhlisin, "Pendistribusian Zakat Untuk Pemberdayaan Masyarakat Pada Badan Amil Zakat Daerah (BAZDA)Kabupaten Karawang” SkripsiUIN Syarif Hidayatullab(2009 : Jakarta), 105.
} 
konsumsi rumah tangga mustahik, baik secara langsung maupun tidak langsung. Selain itu, pendapatan rumah tangga sebagai variabel perantara juga berpengaruh terhadap konsumsi rumah tangga mustahik, peneliti memberikan beberapa saran, antara lain program pemberdayaan melalui zakat produktif diharapkan dapat dilakukan kembali oleh BAZNAS Kota Probolinggo. Diharapkan besarnya dana zakat produktif yang disalurkan untuk masingmasing mustahik dapat ditingkatkan karena zakat produktif mampu meningkatkan pendapatan mustahik sehingga mustahik akan mampu meningkatkan konsumsi rumah tangganya. ${ }^{9}$ Hasil dari diatribusi yang kurang memberikan manfaat seperti pendistribusian zakat yang tidak produktif, hanya akan memberikan manfaat yang instan pada masyarakat, karena harta zakat tidak bisadigunakan untuk kebutuhan bergulir seperti dijadikan modal usaha.

Distribusi zakat dengan cara produktif itu lebih efektif untuk memberikan nilai manfaat pada masyarakata hal ini selaras dengan hasil penelitianyang menyatakan zakat produktif dan zakat konsumtif mampu meningkatkan kesejahteraan sekaligus menurunkan kemiskinan mustahik. Namun demikian, zakat produktif lebih mampu mengurangi kemiskinan dibanding zakat konsumtif. Hal ini disebabkan pemberian zakat produktif oleh amil kepada mustahik selalu diiringi dengan pendampingan usaha yang tidak hanya memberikan informasi mengenai bagaimana cara berbisnis yang baik, tapi juga memberikan bagaimana cara beragama yang benar sesuai dengan ketentuan syariat Islam. Pendidikan agama yang diberikan amil berperan penting dalam meningkatkan pemahaman dan kesadaran beragama mustahik, dan hal ini berperan penting dalam mengeluarkan mustahik dari kemiskinan spiritual. ${ }^{10}$ Dari beberapa sifat dsitribusi zakat, maka distibusi zakat sangat bermanfaat dan bisa menjadi salah satu cara untuk mengembangkan perekonomian umat adalah dengan car produktif. Namun, masih banyak masyarakat yang belum memahami akan manfaat tersebut sehingga masih banyak daerah yang menggunakan sifat ditribusi zakat dengan cara konsumtif tradisional seperti di Desa Karang Penang Sampang.

Harta zakat diarahkan terutama untuk memenuhi kebutuhan pokok hidupnya, seperti kebutuhan makanan, pakaian dan tempat tinggal secara wajar.Kebutuhan pokok yang bersifat primer ini terutama dirasakan oleh kelompok fakir, miskin, gharim, anak yatim piatu, orang jompo/ cacat fisik yang tidak bisa berbuat apapun untuk mencari nafkah demi kelangsungan hidupnya.

\footnotetext{
${ }_{9}$ Elok Nurlita dan Marlina Ekawaty "Pengaruh Zakat Terhadap Konsumsi Rumah Tangga Mustahik (Studi Pada Penerima Zakat Dari BAZNAS Kota Probolinggo) Jurnal Ekonomi Dan Bisnis Islam, Vol. 3, No.2, (Juli-Desember 2017), 103.

${ }^{10}$ Khalifah Muhamad Ali, Nydia Novira Amalia, dan Salahuddin El Ayyubi. "Perbandingan Zakat Produktif dan Zakat Konsumtif dalam Meningkatkan Kesejahteraan Mustahik" Jurnal AlMuгara'ah,Vol.4, No.1, (2016), 31.
} 
Serta bantuan-bantuan lain yang bersifat temporal seperti: zkat fitrah, bingkisan lebaran dan distribusi daging hewan qurban khusus pada hari raya idul adha.

Kebutuhan mereka memang nampak hanya bisa diatasi dengan menggunakan harta zakat secara konsumtif, umpama untuk makan dan minum pada waktu jangka tertentu,pemenuhan pakaian, tempat tinggal dan kebutuhan hidup lainnya yang bersifat mendesak. Dengan demikian, dapat disimpulkan bahwa yang dinamakan fakir miskin yang mendapatkan harta secara konsumtif adalah mereka yang dikategorikan dalam tiga hal perhitungan kuantitatif, antara lain: pangan, sandang dan papan. Pangan asal kenyang, sandang asal tertutupi dan papan asal untuk berlindung dan beristirahat.Pemenuhan kebutuhan bagi mereka yang fakir miskin secara konsumtif ini diperuntukkan bagi mereka yang lemah dalam bidang fisik, seperti orang-orang jompo.Dalam arti kebutuhan itu, pada saat tertentu tidak bisa diatasi kecuali dengan mengkonsumsi harta zakat tersebut.

Karang Penang merupakan daerah yang memiliki jumlah masyarakat sebanyak 14.058 dengan rincian laki-laki 7.980 dan perempuan sebanyak $6.960^{11}$ Dan memiliki potensi untuk mengembagkan dana zakat sebagai salah satu alternatifdalam mengembangkan perekonomian masyarkat Karang Penang. Salah satu sisi ajaran Islam yang belum ditangani secara serius adalah penanggulangan kemiskinan dengan cara mengoptimalkan pengumpulan dan pendayagunaan zakat, infaq dan shadaqah dalam arti seluas-luasnya dan diatribusi zakat di Karang Penang belum bisa maksimal mulai dari manfaat yang diperoleh masyarakat Serta pengembangan ekonomi dari Dana diatribusi zakat belum terlihat. Dengan demikian peneliti tertarik untuk melakukan penelitian mengenai distribusi Dana zakat di Karang Penang.

Penelitian ini menggunakan pendekatan kualitatif (qualitative approach) atau penelitian lapangan (field research) yaitu penelitian yang menggunakan data dan sumber informasi lapangan, yang bertujuan untuk memperoleh data-data yang diperlukan dari objek penelitian yang sebenarnya, dan untuk mempelajari secara intensif latar belakang, status yang terjadi pada suatu satuan social seperti individu, kelompok masyarakat, tokoh masarakat, lembaga atau komunitas. Peneliti mengmbil informasi dari fenomena yang terjadi sebagai satu kesatuan yang utuh, untuk dijadikan sebagai sumber. Pendekatan ini akan memudahkan peneliti dalam menemukan persoalan-persoalan ganda, mendekatkan diri peneliti dengan subyek yang diteliti, serta lebih peka dan lebih dapat menyesuaikan diri terhadap pengaruh fenomena yang ada di lapangan.

Penelitian ini juga merupakan kajian kepustakaan yang didukung oleh data-data lapangan.Penelitian ini menggunakan beberapa pendekatan kajian.Pertama, yuridis normative dan pendekatan yuridis empiris.Penelitian

\footnotetext{
${ }^{11}$ Dokumentasi Data Masyarakat Kepala Desa Karang Penang Oloh Juni 2019.
} 
yuridis normatif adalah penelitian yang membahas doktrin-doktrin atau asasasas dalam ilmu hukum, baik yang terdapat dalam Al-Qur'an, Hadist maupun dalam peraturan perundang-undangan yang mengutamakan pemikiran dan pendapat para ulama tentang kombinasi akad dalam transaksi muamalah, khususnya transaksi dengan jaminan/collateral.Adapun pendekatan yuridis empiris, yaitu penelitian terhadap efektivitas hukum yang menggunakan pengumpulan data melalui wawancara dan dokumentasi.Pendekatan etika teori dan beberapa teori yang digunakan. Pertama, kesesuaian terhadap fatwa digunakan untuk membaca gejala dan pola serta mengkategorikan praktek keuangan syariah dan kombinasi akad produk pembiayaan syariah dalam kriteria-kriteria kesyariahan tertentu. Kedua, teori kontrak digunakan untuk membaca kombinasi kontrak atau akad. Selain itu, perlu dikemukakan bahwa penelitian ini bersifat deskriptif analisis untuk memberikan gambaran mengenai fakta-fakta riil disertai analisis yang akurat terhadap

Lokasi peneltian adalah masyarakat Karan Penang Oloh Sampang. Penetapan lokasi penelitian ini didasarkan atas keputusan peneliti dengan melihat adanya kenyataan bahwa distribusi zakat di Karang Penang Oloh Sampang cukup besar, namun belum tergali secara maksimal karena metode yang digunakan adalah distribusi zakat konsumtif tradisional dan melihat penduduk Karang Penang yang seluruhnya penduduk muslim. Sedangkan obyek dalam penelitian ini adalah masyarakat yang memberikan zakat serta amil yang ditunjuk oleh perorangan seperti tokoh masyarakat dan tokoh agama.Peneliti menggunkana tehnik wawancara yang tidak terstruktur kepada tokoh-tokoh dan masyarakat, menggunakan data dokumentasi dari perangkat desa serta melalui observasi lapangan dengan melihat fenomena pendistribusian zakat.

\section{Konstruksi Terminologi Distribusi Zakat}

Zakat adalah salah satu kewajiban agama yang tinggi nilainya, bahkan masuk dalam rangkaian rukun Islam yang lima. Melalaikan kewajiban zakat bukan hanya dosa besar, tapi pada gilirannya bisa sampai kepada kekufuran, yaitu bila kita mengingkari kewajibannya. ${ }^{12}$ Zakat diberikan kepada siapa saja yang ada yang termasuk delapan golongan yang dijelaskan dalam Islam, sedikitnya tidak boleh kurang dari tiga orang (yang diberi zakat) dalam setiap golongannya kecuali amil (maka boleh satu orang saja) ${ }^{13}$ sehingga harta zakat akan memberikan nilai manfaatpada golongan yang disebutkan dalam syariah.

12 Ahmad Sarwat, Zakat Uang(Jakarta: Rumah Fiqih PublishingJalan Karet Pedurenan No. 53 Kuningan Setiabudi, 2019), 6.

${ }^{13}$ Galih Maulana, Terjemah Matan Al-Ghayah Was At-Taqrib Al-Qhadi Abi Syuja 3 Zakat Puasa Haji(Jakarta: Rumah Fiqih PublishingJalan Karet Pedurenan No. 53 Kuningan Setiabudi, 2019), 18. 
Zakat merupakan salah satu rukun Islam yang ketiga, zakat merupakan suatu ibadah yang paling penting kerap kali dalam Al-Qur'an, Allah menerangkan zakat beriringan dengan menerangkan shalat.Pada delapan puluh dua tempat Allah menyebut zakat beriringan dengan urusan shalat ini menunjukan bahwa zakat dan shalat mempunyai hubungan yang rapat sekali dalam hal keutamaannya shalat dipandang seutama-utama ibadah badaniyah zakat dipandang seutama-utama ibadah maliyah. Zakat merupakan salah satu rukun Islam, dan menjadi salah satu unsur pokok bagi tegaknya syariat Islam. Oleh sebab itu hukum zakat adalah wajib (fardhu) atas setiap muslim yang telah memenuhi syarat-syarat tertentu. Zakat termasuk dalam kategori ibadah (seperti shalat, haji, dan puasa) yang telah diatur secara rinci dan paten berdasarkan AlQur'an dan As Sunnah, sekaligus merupakan amal sosial kemasyarakatan dan kemanusiaan yang dapat berkembang sesuai dengan perkembangan umat manusia.

Hukum mengeluarkan zakat adalah wajib, dalam zakat fitrah yang dibayarkan zakat yaitu berupa makanan pokok sebesar 3,1 liter atau 2,5 $\mathrm{kg}$ atau bisa juga dibayarkan dengan uang senilai makanan pokok yang harus dibayarkan. Sedangkan yang dibayarkan zakat mal berupa binatang ternak, emas dan perak, biji-bijian dan buah-buahan, rikaz, dan hasil tambang.

Syarat wajib zakat fitrah adalah beragama Islam, lahir dan hidup sebelum terbenam matahari pada hari penghabisan bulan Ramadhan, dan mempunyai persediaan makanan untuk dirinya sendiri dan yang wajib dinafkahi, baik manusia atau binatang, pada malam hari raya dan siang harinya. Dan syarat wajib zakat mal adalah Islam, merdeka, hak milik sempurna, sampai nisab, dan masa memiliki sampai satu tahun. Sedangkan penerima zakat Orang-orang yang berhak menerima zakat yaitu orang fakir, orang miskin, amil, muallaf, hamba sahaya, orang yang berhutang, fi sabilillah, dan ibnu sabil. Sedangkan yang tidak berhak menerima zakat yaitu orang kafir, orang atheis, keluarga Bani Hasyim dan Bani Muttalib, dan ayah, anak, kakek, nenek, ibu, cucu, dan isteri yang menjadi tanggungan orang yang berzakat.

Zakat juga bisa diartikan bersih menurut bahasa, tambah dan terpuji. Sedangkan menurut istilah zakat adalah kadar harta tertentu yang diberikan kepada para mustahiq (yang berhak) menerimanya dengan beberapa syarat Adapun dalam pembahasan fikih, istilah zakat diartikan sebagai sejumlah harta tertentu yang wajib dikeluarkan dan diserahkan kepada orang-orang yang berhak menerimanya. ${ }^{14}$ Sehingga para muzakki akan merasakan nilai positif berupa kepuasan, ketentraman dan kebhagiaan dengan distribusi zakat.Seluruh ulama Salaf dan Khalaf menetapkan bahwa mengingkari hukum zakat yakni

${ }^{14}$ Indi Aunullah, Ensiklopedi Fikib untuk Remaja Jilid 2 ,(Yogyakarta : Pustaka Insan Madani), 314. 
mengingkari wajibnya menyebabkan di hukum kufur. Karena itu kita harus mengetahui definisi dari zakat, harta-harta yang harus dizakatkan, nishabnishab zakat, tata cara pelaksanan zakat dan berbagai macam zakat.

Dengan demikian zakat merupakan bagian penting dalam kehidupan umat Islam. Bahkan pada masa Khalifah Abu Bakar As-Siddiq orang-orang yang enggan berzakat diperangi sampai mereka mau berzakat. Itu karena kewajiban berzakat sama dengan kewajiban mendirikan sholat. ${ }^{15}$ Kewajiban zakat atas muslim adalah di antara kebaikan Islam yang sangat optimal dan perhatianya terhadap perkara para pemeluknya, hal itu karena begitu banyak manfaat zakat dan betapa besar kebutuhan orang-orang fakir kepada zakat. Namun sayang, zakat yang seharusnya menjadi potensi optimal bagi ekonomi umat, pada umumnya belum digarap secara baik. Akibatnya kemiskinan di kalangan umat Islam jumlahnya masih cukup banyak. Padahal kita pun tahu bahwa kemiskinan dan kemelaratan merupakan bibit potensial untuk kemurtadan dan kekufuran. Sehingga pengembangan dana zakat dibutuhkan untuk menghilangkan keterbelakangan perekonomian umat.

Ada banyak cara yang dilakukan untuk memaksimalkan peran orang kaya dalam keterlibatannya untuk mensejahterakan orang-orang miskin. Upaya yang dilakukan tidak hanya dibatasi dengan bersedekah dan memerdekakan sebagaimana dikatakan dalam hadis di atas. Beberapa upaya lainnya yang dapat dilakukan adalah dengan bermitra usaha, menjalin hubungan perburuhan, melalui mekanisme pasar, dan melalui mekanisme zakat ${ }^{16}$ melalui mekanisme zakat ini akan sangat membantu perekonomian masyarkat jika zakat didistribusikan dengan cara produktif.

\section{Distribusi Zakat Secara Konsumtif Tradisonal Di Karang Penang Sampang}

Dalam distribusi konsumtif dana zakat ini dapat menggunakan cara Tradisional dan kreatif. Cara tradisional dilakukan dengan membagikan dana zakat kepada mustahiq dengan secara langsung untuk kebutuhan konsumsi sehari-hari masyarakat. Misalnya pembagian zakat fitrah berupa uang dan beras kepada fakir miskin setiap idul fitri. Begitu pula dengan praktik zakat di Karang Penang yang dinyatakan oleh M. Dari pembagian zakat maal sudah menjadi adat dibagikan pada saat bulan puasa pada minggu terahir dengan besaran uang senilai dengan harga $3 \mathrm{Kg}$ beras, misalnya harga beras Rp 10.000,00 maka masyarakat akan mendapatkan uang zakat sebesar Rp 30.000,00/orang dan

\footnotetext{
${ }^{15}$ Tim Abdi Guru, Agama Islam Untuk SMP Kelas VIII, (Jakarta : Erlangga, 2005), 150.

16Aden Rosadi dan Mohamad Anton Athoillah,"Distribusi Zakat di Indonesia: Antara Sentralisasi dan DesentralisasiIjtihad", Jurnal Wacana Hukum Islam dan Kemanusiaan Vol. 15, No. 2 (2015), 103.
} 
besaran ini berlaku pada semua orang yang berhak mendapatkan harta zakat. ${ }^{17}$ Distribusi zakat ini, akan berfungsi dalam jangka pendek untuk kebutuhan masyarakat dan akan membantu untuk membeli kebutuhan pada saat ramadhan atau lebaran saja. Zakat mal waktunya tidak ditentukan, sedangkan zakat fitrah dibagi menjadi 5, yaitu waktu mubah, wajib, sunah, makruh dan waktu haram.

Pola ini merupakan program jangka pendek dalam mengatasi permasalahan umat.Amil zakat disebutkan di dalam Al-Quran sebagai pihak yang berhak menerima harta zakat dengan nomor urut tiga, setelah fakir dan miskin Posisi nomor tiga ini tentu bukan tanpa pesan.Pesannya menunjukkan betapa pentingnya peran Dan istilah ini sesuai dengan tugasnya, yaitu berkeliling secara aktif mengumpulkan harta zakat dari mereka yang termasuk wajib zakat.Selain itu juga berkeliling untuk membagikan harta zakat kepada orangorang yang berhak (mustahiq) atas harta zakat. ${ }^{18}$ Begitu juga yang ada di Karang penang menurut pernyataan Ustad Muhammad Rizal bahwa pembagian zakat juga bisa dilakukan oleh amil, amil tersebut ditunjuk oleh muzakki yang dipercayakan untuk membagikan harta zakat. ${ }^{19}$ Zakat merupakan instrument umat muslim untuk menjadi jembataan pendistribusian kekayan yang dimiliki untuk bisa membatu beberapa kelompok yang membutuhkan

Pernyataan Marsiyah zakat dilarang Penang dibagikan dengan cara langsung oleh muzakki kepada masyaraka sekitar, berkisar Rp 20.000,00 sampai Rp 50.000,00, adakalanya Rp 100.000,00 jika yang memberikan zakat adalah family atau keluarga. Dai zakat ini biasanya masyarakat menggunakan untuk membeli kebutuhan yang sederhanasaja misalnya untuk beli beras, minyak goreng atau digunakan oleh masyarakat untuk mengeluarkan zakat fitrah karena masyarakat Karang Penang selalu mengeluarkan zakat maal pada bulan puasa di dua minggu terahir. ${ }^{20}$ Secara teoritik, hukum-hukum agama (syari at Islam) mewajibkan zakat dan menekankan untuk zakat didistribusikan karena zakat memiliki potensi untuk mengembagkan perekonomian, zakat merupakan pemberian sebagian harta kepada fakir miskin dan orang-orang yang berhak menerimanya dan hukumnya wajib. ${ }^{21}$ Zakat dibagi menjadi 2, yaitu zakat fitrah dan zakat mal. Zakat fitrah merupakan zakat yang dikeluarkan umat Islam pada sebagian bulan Ramadhan dan sebagian bulan Syawal untuk mensucikan jiwa.

\footnotetext{
${ }^{17}$ Wawancara dengan M.Dari Guru Sekolah Menengah Pertama Sunan Drajat Bulmatet karang Penang, Pada tanggal 24 Oktober 2019.

${ }^{18}$ Hanif Luthfi, Siapakah Amil Zakat? (Jakarta : Rumah Fiqih PublishingJalan Karet Pedurenan no. 53 Kuningan Setiabudi, 2018), 8.

${ }^{19}$ Wawancara dengan Muhammad Rizal, Ustad Madrasah Nurul Banat karang Penang, Pada tanggal 24 Oktober 2019.

${ }^{20}$ Wawancara dengan Marsiyah Masyarakat Penerima Zakat Karang Penang, pada tanggal 12 September 2019.

${ }^{21}$ Hussein Bahreisj, 450 Masalah Agama Islam, (Surabaya : Al Ikhlas), 226.
} 
Sedangkan zakat mal adalah zakat harta yang dimiliki seseorang karena sudah mencapai nisabnya.

Serta pemberian tertentu dari harta tertentu kepada orang tertentu menurut syarat-syarat yang ditentukan". ${ }^{22}$ Karena zakat berbeda denga distribusi harta lainnya misalnya perbedaan zakat dengan sedekah, zakat hukumnya wajib sedangkan sedekah yang hukumnya sunnah tidak ditetapkan berapa besarnya. Seseorang boleh menyedekahkan berapa saja dari hartanya, seikhlasnya dan sesukanya.Boleh lebih dari zakat atau juga boleh kurang.Yang juga cukup unik dari zakat adalah disebutkan adanya orang-orang yang secara khusus bekerja untuk mengumpulkan zakat dan mendistribusikannya. ${ }^{23}$ Penyebutan khusus dalam pengelolaan mulai dari pengumpulan zakat sampai distribusi zakat Serta penerima zakat juga orang-orang tertentu,demikian merupakan bentuk dana atau harta yang harus dikelola dengan baik Serta memiliki potensi untuk mengembangkan perekonomian umat, serta pereknomian yang sesuai syariah untuk mengembangka ekonomi dengan nilai value untuk dunia dan akhirat.

Serta orientasi utama sistem ekonomi syariah adalah untuk merealisasikan kebahagiaan yang sebesar-besarnya bagi individu dan masyarakat, baik di dunia maupun di akhirat. ${ }^{24}$ Islam sama sekali tidak mengizinkan umatnya untuk mendahulukan kepentingan ekonomi di atas pemeliharaan nilai dan keutamaan yang diajarkan agama. Saat ini kita mendapatkan sistem-sistem lain yang lebih mendahulukan usaha-usaha ekonomi dengan mengabaikan akhlak dan berbagai konsekuensi keimanan. ${ }^{25}$ Dengan demikian para pelaku ekonomi Islam dalam berprilaku dan pengambilan keputusan dalam setiap unit kegiatatn atau aktivitas ekonomi dengan mendasarkan pada tata aturan moral dan etika syariah ${ }^{26}$ Sehingga nilai taawun dari zakat terealisasi.

Zakat di Karang Penang juga didistribusikan melalui amil zakat yang ditunjuk oleh muzakki itu sendiri seperti tokoh masyarakat dan tokoh agama.Namun, amil zakat disini tidak mencari para muzakki. Akan tetapi, amil zakat ditunjuk langsung oleh muzakki kemudian amil zakat akan memberikan harta zakat kepada warga sekitar. Sesuai dengan pernyataan Abdur Rouf Karang

${ }^{22}$ Amir Syarifuddin. Garis-garis Besar Figh, (Bogor: Kencana), 37.

23 Ahmad Sarwat,Zakat Rekayasa Genetika (Jakarta: Rumah Fiqih Publishing Jalan Karet Pedurenan no. 53 Kuningan Setiabudi 2018), 36.

${ }^{24}$ Hasbi Hasan, Pemikiran dan Perkembangan Hukum Ekonomi Syariah di Dunia IslamKontemporer (Jakarta: Gramata Publishing, 2011), 30.

${ }^{25}$ Andi Iswandi,Peran Etika Qur'ani Terbadap Sistem Ekonomi Islam"Jurnal Al-Iqtishad Ilmu Ekonomi Syariah, Vol. VI. No. 1”(Jakarta: UIN Syarif Hidayatullah, Januari 2014), 151.

${ }^{26}$ Euis Amalia,Mekanisme Pasar dan Kebijakan Penetapan Harga Adil dalam Perspektif

Ekonomi Islam 'Jurnal Al-Iqtishad Ilmu Ekonomi Syariah, Vol. V, No.1,”(Jakarta: UIN Syarif Hidayatullah, Januari 2014), 151. 
Penang juga melakukan distribusi zakat dengan cara menunjuk satu amil yang ditunjuk oleh muzakki untuk mengumpulkan musatahik dan mendistribusikan dana zakat tersebut. Cara ini bias any dilakukan oleh para perantau misalnya ada beberapa keluarga yang bekerja di Malaysia maka beberapa keluarga tersebut akan menunjuk satu amil untuk mengumpulkan uang dari beberapa keluarga kemudian akan membagikan ke masyarakat secara merata. ${ }^{27}$

Menurut Muhammad Rizal pendistribusian dana zakat dilakukan dengan memberikan uang zakat sekitar Rp 17.000,00/per orang dan dibagikan kepada semua orang yang menjadi jamaah hataman di yayasan Wali Songo Karang Penang, semua jamaah akan mendapatkan dana zakat ini meskipun mampu dalam ekonomi, karena jamaah secara keseluruhan ekonominya lebih rendah dari pemilik yayasan sehingga semua akan mendapatkan. Meskipun ada beberapa orang yang mampu dari ekonomi, akan tetapi harta yang dimiliki tidak lebih dari yang dimiliki oleh yayasan. ${ }^{28}$ Cara kreatif ini dilakukan dengan cara dana zakat yang diwujudkan dalam bentuk barang konsumtif dengan pemberian bantuan untuk pelajar (ngaji) pola ini digunakan untuk membantu orang miskin dalam mengatasi permasalahan sosial dan ekonomi yang dihadapi dalam jangka pendek.

Begitu pula yang dinyatakan oleh Ropi'ah bahwa pembagian zakat di daerah Karang Penang dengan metode konsumtif seperti yang dilakukan kyai dengan memberikan dana zakat kepada para guru pengajar madrasah yang masuk kategori masyarakat kuarang mampu, misalnya berupa uang $\mathrm{Rp}$ 30.000,00 dan biasanya dijelasin oleh pengasuh bahwa uang tersebut merupakan uang pembagian zakat, karena para guru biasanya diakhir bulan Ramadhan akan mendapatkan dana zakat, dan THR. ${ }^{29}$

Pola pendistribusi zakat di Karang Penang Sampang dilakukan secara konsumtif tradisional tidak memberikan nilai untuk mengembangkan perekonomian masyarakat hal ini sesuai dengan pernyataan Hermanto Dari pemberian zakat biasanya dikumpulkan dan didistribusikan pada bulan puasa baik zakat fitrah ataupun zakat maal besaran dana zakat yang diadapatkan oleh masyarakat juga tidak besar hanya berkisar Rp 30.000,00 sampai Rp 50.000,00 dan diantarkan oleh seseoarang yang ditunjuk oleh muzakki, kemudian para pengantar akan mendapatkan uang jasa Rp 100.000,00/20 orang asnaf. ${ }^{30} \mathrm{Hal}$ ini

\footnotetext{
${ }^{27}$ Wawancara dengan Abdur Rouf Guru Ngaji di Karang Penang, pada tanggal 10 September 2019.

${ }^{28}$ Wawancara dengan Hermanto Guru Madrasah Nurul Banat Yayasan Wali Songo Karang Penang, pada tanggal 24 Oktober 2019.

${ }^{29}$ Wawancara dengan Ropi'ah Guru Madrasah Ibtidaiyah Wali Songo Karang Penang, pada tanggal 15 Oktober 2019.

${ }^{30}$ Wawancara dengan Hermanto Guru Madrasah Ibtidaiyah Wali Songo Karang Penang, pada tanggal 24 Oktober 2019.
} 
menunjukkan bahwa zakat merupakan instrument penting untuk dikelola dalam mengembangkan perekonomian dan menunjang perekonomian masyarakat.

Aden Rosadi dan Mohamad Anton Athoillah menyatakan bahwa banyaknya faktor yang menjadi penyebab lahirnya kemiskinan, semuanya harus disentuh dan diselesaikan. Upaya yang dapat dilakukan untuk menyentuh dan menyelesaikan faktor-faktor penyebab kemiskinan di atas adalah melalui distribusi dana zakat secara adil dan menyeluruh. Distribusi ini tidak dapat dilakukan secara personal dan tanpa rencana, kecuali melalui kelembagaan dan perencanaan yang sesuai sehingga tujuan adanya distribusi dana zakat ini tercapai. ${ }^{31} \mathrm{Hal}$ ini selaras dengan pernyataan Afan Aridi bahwa pembagian zakat jika dilakukan secara produktif misalnya dana zakat tersebut dikelola oleh paratur desa, kemudian dibuat usaha maka akan lebih terlihat manfaatnya. ${ }^{32}$

Hal ini sesuai juga dengan penelitian yang menyatakan Zakat produktif yang disalurkan oleh BAZNAS JATIM memiliki peranan dalam meningkatkan kinerja produksi mustahiq, dikarenakan zakat produktif yang disalurkan dalam bentuk modal usaha kepada mustahiq dapat meningkatkan indikator-indikator kinerja yang telah ditentukan. Indikator utama, yaitu indikator kuantitatif, adalah perubahan jumlah kuantitas bahan baku, kuantitas output produksi yang dihasilkan, dan frekuensi produksi yang dilakukan. Lalu juga dari indicator tambahan seperti efektivitas sumber daya yang digunakan yaitu pengeluaran tambahan produksi (Faktory Overhead) ${ }^{33}$ Dari beberapa paparan data penelitian sebelumnya bisa dikatakan bahwa disribusi zakat di Karang Penang tidak maksimal dalam upaya mengembangkan perekonomian umat.

Namun yang menjadi kendala di Karang Penang saat ini kurangnya kesadaran masyarakat akan kewajiban zakat, kurangnya pembinaan dalam mengelola dana zakat. Sesuai dengan pernyataan Wadud bahwa seandainya zakat dikelola dan distribusikan dengan cara produktif maka manfaat akan dirasakan oelh masyarakat dan akan menunjang perekonomian masyarakat. Namun, sampai saat ini di Karang Penang belum bisa diterapkan karena beberapa faktor antara lain; ideologi masyarakat masih menganggap dana zakat yang diserahkan kepada ulama atau tokoh agama lebih memberikan kebarokahan pada hartaya, kurangnya kesadaran masyarakat akan wajib zakat, kurangnya pengetahuan pada pengelola dana zakat, dan kurangnya kepercayaan

\footnotetext{
${ }^{31}$ Aden Rosadi Dan Mohamad Anton Athoillah Ijtihad, "Distribusi Zakat di Indonesia: Antara Sentralisasi dan Desentralisasi" Jurnal Wacana Hukum Islam Dan KemanusiaanVol. 15, No. 2 (2015), 238.

32 Wawancara dengan Afan Aridi masyarakat Karang Penang, pada tanggal 01 November 2019.

${ }^{33}$ Herwindo Ghora Nidityo dan Nisful Laila, "Zakat Produktif Untuk Meningkatkan Kinerja Produksi, Motivasi Dan Religiusitas Mustahiq (Studi Kasus Pada BAZ JATIM)"JESTT Vol. 1 No. 9 (September 2014), 672
} 
masyarakat pada lembaga pengelola zakat baik swasta mauoun negeri. ${ }^{34}$ Dari beberapa faktor tersebut, maka distribusi zakat di Karang Penang masih menggunakan metode distribusi konsumtif tradisional.

Hal lain serupa juga diungkapakn oleh Haris bahwa sampai saat ini di Karang Penang belum ada pihak pemerintah yang mensosialisasikan mengenai pengelolaan zakat yang baik dan memberikan peningkatan perekonomian masyarakat. Sehingga ideologi masyarakat tetap saja dengan pola tradisional, padahal masyarakat karang Penang memiliki potensis perekonomian meningkat dari dana zakat karena masyarakat Karang Penang merupakan masyarakat yang berkembang dengan beberapa mata pencahariannya. ${ }^{35}$ Pengelolaan dana zakat harus didampingi oleh pemerintah agar kesenjangan ekonomi di masyarakat bisa diatasi dengan distribusi zakat, karena perubahan pola piker masyarakat yang akan merubah cara distribusi zakat yang konsumtif tradisonal kepada distribusi zakat yang produktif modern.

Zakat di Karang Penang didistribusikan dengan cara konsumtif tradisional disebabkan beberapa hal, antara lain: kurangnya pemahaman dan kesadaran masyarakat akan kewajiban zakat, ketidak tahuan masyarakat akan manajemen distribusi zakat, kurangnya perhatian pemerintah dalam sosialisasi lembaga amil zakat serta kurangnya perhatian pemerintah dalam memberikan pendampingan kepada aparat desa mengenai pengelolaan zakat produktif.

Dari distribusi zakat tersebut ada beberapa manfaat yang peroleh antara lain; menolong orang yang lemah dan menderita, agar dia dapat menunaikan kewajibannya terhadap Allah dan terhadap makhluk-Nya, membersihkan diri dari sifat kikir dan akhlak yang tercela serta mendidik diri agar memiliki sifat mulia dan pemurah, ungkapan rasa syukur kepada Allah atas rizki yang telah diberikan kepada kita, menjaga kejahatan-kejahatan yang dimungkinkan timbul dari si miskin dan mendekatkan hubungan kasih sayang dan saling mencintai antara si kaya dan si miskin

\section{Kesimpulan}

Berdasarkan pemaparan-pemaran di atas dapat disimpulkan bahwa penelitian ini menunjukkan bahwa praktik distribusi zakat di Karang Penang Sampang dengan strategi konsumtif tradisional. Cara distribusi zakat pertama, Mustahiq mendistribusikan harta zakat secara langsung pada masyarakat yang berhak untuk menerima zakat dalam bentuk uang tunai dan mustahiq mengantarkan sendiri kepada orang-orang yang berhak atau menyuruh salah satu orang yang dianggap amanah untuk mengantarkan harta zakat tersbut.Kedua, mustahiq mengantarkan harta zakat ke tokoh masyarakat atau

\footnotetext{
34 Wawancara dengan Wadud masyarakat Karang Penang, pada tanggal 02 November 2019.

35 Wawancara dengan Wadud masyarakat Karang Penang, pada tanggal 02 November 2019.
} 
tokoh agama untuk diberikan kepada masyarakat sekitar yang berhak menerima zakat.

Beberapa faktor masyarakat Karang Penang mendistribusikan zakat dengan cara konsumtif tradisional antara lain; ideologi masyarakat masih menganggap dana zakat yang diserahkan kepada ulama atau tokoh agama lebih memberikan kebarokahan pada hartaya, kurangnya kesadaran masyarakat akan wajib zakat, kurangnya pengetahuan pada pengelola dana zakat, dan kurangnya kepercayaan masyarakat pada lembaga pengelola zakat baik swasta mauoun negeri serta kurangnya sosialisasi lembaga pengelola zakat pada masyarakat Karang Penang.

Nilai positif dari distribusi zakat melalui strategi konsumtif tradisional hanya memberikan nilai positif tidak maksimal kepada masyarakat karena mayoritas uang yan diperoleh dari dana zakat tersebut akan digunakan untuk membeli kebutuhan yang sederhana saja tanpa bisa digunakan untuk pengembangan ekonomi. Sehingga strategi ini dirasa kurang maksimal untuk digunakan di karang penang melihat masyarakat yang memiliki potensi untuk mengembangkan dana zakat.

\section{Daftar Pustaka}

Aunullah, Indi Ensiklopedi Fikih untuk Remaja Jilid 2, Yogyakarta : Pustaka Insan Madani 2008.

Ali, Khalifah Muhamad Nydia Novira Amalia, dan Salahuddin El Ayyubi. "Perbandingan Zakat Produktif dan Zakat Konsumtif dalam Meningkatkan Kesejahteraan Mustahik" Jurnal Al-Murara'ah, Vol.4, No.1, 2016.

Bahreisj, Hussein 450 Masalah Agama Islam, Surabaya : Al Ikhlas 1980.

Dokumentasi Data Masyarakat Kepala Desa Karang Penang Oloh Juni 2019.

Fakhriah,'Dini Efektivitas Penyaluran Dana Zakat Di BAZNAS Kota Bekasi

Dalam Peningkatan Pendidikan Melalui Program Bekasi Cerdas"

Skripsi, Konsentrasi Manajemen Zakat Dan Wakaf Program Studi

Mumalah Fakultas Syariah UIN Syarif Hidayatulh Jakarta 2016.

Hidayat, Achmad Syaiful "Model Tatakelola Badan Dan Lembaga Amil Zakat

Sebagai Upaya Untuk Meningkatkan Pemberdayaan Ekonomi

Masyarakat (Studi Pada Badan/Lembaga Amil Zakat Di Kota Malang)" Anwar Jurnal Humanity, ISSN: 0216-8995 Vol. 7, No. 2, Juli 2012.

Irfan Syauqi Beik "Analisis Peran Zakat dalam Mengurangi Kemiskinan : Studi

Kasus Dompet Dhuafa Republika Zakat \& EmpoweringJurnal Pemikiran dan Gagasan - Vol II Agustus 2009.

Luthfi, Hanif Siapakah Amil Zakat?] akarta : Rumah Fiqih Publishing Jalan Karet Pedurenan No. 53 Kuningan Setiabudi, 2018. 
Maulana, Galih Terjemah Matan Al-Ghayah Was At-Taqrib Al-Qhadi Abi Syuja 3 Zakat Puasa Hajijakarta: Rumah Fiqih Publishing Jalan Karet Pedurenan No. 53 Kuningan Setiabudi, 2019.

Mukhlisin, Pendistribusian Zakat Untuk Pemberdayaan Masyrakat Pada Badan Amil Zakat Daerah (BAZDA)Kabupaten Karawang UIN Syarif Hidayatullah Jakarta 2009.

Nidityo, Herwindo Ghora dan Nisful Laila, "Zakat Produktif Untuk Meningkatkan Kinerja Produksi, Motivasi Dan Religiusitas Mustahiq (Studi Kasus Pada BAZ JATIM)"JESTT Vol. 1 No. 9 September 2014.

Nurlita, Elok dan Marlina Ekawaty "Pengaruh Zakat Terhadap Konsumsi Rumah Tangga Mustahik (Studi Pada Penerima Zakat Dari BAZNAS Kota Probolinggo) Jurnal Ekonomi Dan Bisnis Islam, Vol. 3, No.2, JuliDesember 2017.

Nopiardo, Widi "Mekanisme Pengelolaan Zakat Produktif Pada Badan Amil Zakat Nasional Tanah Datar" JEBI (Jurnal Ekonomi dan Bisnis Islam)Vol. 1, No. 2 Juli-Desember 2016.

Pratama, Yoghi Citra "Peran Zakat Dalam Penanggulangan Kemiskinan (Studi Kasus : Program Zakat Produktif Pada Badan Amil Zakat Nasional)" The Journal Of Taubidinomics Vol. 1 No. 1, 2015.

Rosadi, Aden dan Mohamad Anton Athoillah Ijtihad, "Distribusi zakat di Indonesia: antara sentralisasi dan desentralisasi" Jurnal Wacana Hukum Islam dan KemanusiaanVol. 15, No. 2, 2015.

Sarwat, Ahmad Zakat Uangjakarta: Rumah Fiqih Publishing Jalan Karet Pedurenan No. 53 Kuningan Setiabudi, 2019.

Sarwat, AhmadZakat Rekayasa Genetika Jakarta: Rumah Fiqih Publishing Jalan Karet Pedurenan No. 53 Kuningan Setiabudi 2018.

Syarifuddin, Amir Garis-garis Besar Fiqh, Bogor: Kencana, 2003.

Tim Abdi Guru, Agama Islam Untuk SMP Kelas VIII, Jakarta : Erlangga 2005.

Utamy, Hebby Rahmatul "Keadilan Ekonomi Dalam Pendistribusian Zakat Oleh Badan Amil Zakat Nasional (Baznas) Kabupaten Tanah Datar" Jurnal Tamwil, Vol.I, No. 2 Juli-Desember 2015. 